Diajukan: 10-01-2019 | Revisi: 01-03-2019 | Diterima: 05-03-2019

\title{
Peningkatan Mutu Pengelolaan TPA Assakinah
}

\author{
Novi Puji Lestari ${ }^{1}$, Haryo Prasodjo ${ }^{2}$, Hafid Adim Pradan ${ }^{3}$ \\ Fakultas Ekonomi dan Bisnis, Universitas Muhammadiyah Malang ${ }^{l}$ \\ Fakultas Ilmu Sodial dan Ilmu Politik, Universitas Muhammadiyah Malang ${ }^{23}$
}

\begin{abstract}
Daycare purpose of providing services to children aged 0 - 6 years who are forced to leave their parents because of work or other obstacles, in addition to providing services related to the fulfillment of children's rights to grow and develop, get protection and affection, and the right to participate in their social environment. TPA is a service that organizes education and care for children from birth to the age of six (with the priority of children under the age of 4 years). The Community Service program is focused on improving the quality and management of As Sakinah Dau's daycare in order to create a child-friendly and attractive form of child care like most daycare centers. The Child Care Center has been established for a long time but in terms of school profile and other information related to supporting schools is quite less.
\end{abstract}

Keywords: Daycare; website; company profile.

Abstrak

Taman Penitipan Anak memiliki tujuan memberikan layanan kepada anak usia $0-6$ tahun yang terpaksa ditinggal orang tua karena pekerjaan atau halangan lainnya, Selain itu juga memberikan layanan yang terkait dengan pemenuhan hak-hak anak untuk tumbuh dan berkembang, mendapatkan perlindungan dan kasih sayang, serta hak untuk berpartisipasi dalam lingkungan sosialnya. TPA merupakan layanan PAUD yang menyelenggaran pendidikan sekaligus pengasuhan terhadap anak sejak lahir sampai dengan usia enam tahun (dengan prioritas anak usia di bawah 4 tahun). Program Pengabdian ini difokuskan pada peningkatan mutu dan pengelolaan tempat penitipan anak (daycare) As Sakinah Dau agar bisa menciptakan bentuk penitipan anak yang ramah anak dan menarik seperti layaknya tempat penitipan anak pada umumnya. Tempat Penitipan Anak ini sudah lama berdiri tetapi dari sisi profil sekolah dan informasi lain terkait sekolah yang menunjang juga belum ada.

Kata Kunci: Taman pendidikan anak; website; company profile.

\section{Pendahuluan}

Tempat Penitipan Anak (TPA) merupakan salah satu bentuk Pendidikan Anak Usia Dini (PAUD) yang secara tegas diamanatkan oleh Undang-undang No. 20 Tahun 2003 tentang Sistem Pendidikan Nasional. Dalam UU tersebut dijelaskan bahwa PAUD adalah "suatu upaya pembinaan yang ditujukan kepada anak sejak lahir sampai dengan usia enam tahun yang dilakukan melalui pemberian rangsangan pendidikan untuk membantu pertumbuhan dan perkembangan jasmani dan rohani agar anak memiliki kesiapan dalam memasuki pendidikan lebih lanjut". Dalam pelaksanaannya PAUD dapat dilaksanakan melalui jalur formal maupun jalur nonformal. Jalur formal antara lain melalui Taman Kanak-kanak (TK) dan Raudhatul Anfal (RA) sedangkan jalur non-formal dapat berbentuk Taman Penitipan Anak (TPA), Kelompok Bermain (Kober) dan bentuk lainnya yang sederajat.

Tempat Penitipan Anak As Sakinah merupakan Taman Pendidikan yang berlokasi di Desa Dermo Kecamatan Dau Kabupaten Malang. Jika dilihat dari jumlah anak didik yang mendaftar pada setiap kali penerimaannya, dapat berkisar dari angka 25-30 anak. Beberapa keunggulan yang dimiliki oleh TPA As Sakinah adalah ruang cukup besar yang memiliki kapasitas daya tampung yang cukup besar. Pendidikan Anak Usia Dini yang diterapkan dalam program Taman Penitipan Anak hendaknya sesuai dengan prinsipprinsip yaitu berorientasi pada kebutuhan anak, sesuai dengan perkembangan anak, sesuai dengan keunikan setiap individu, kegiatan belajar mengajar dilakukan dengan metode bermain, anak belajar dari yang konkrit ke abstrak, anak sebagai pembelajar aktif, menyediakan lingkungan yang bagus untuk belajar, merangsang munculnya kreativitas dan inovatif.

Pada dasarnya setiap anak memiliki kebutuhan dasar yang sama, seperti kebutuhan fisik, rasa aman, dihargai, tidak dibeda-bedakan, bersosialisasi, dan kebutuhan untuk diakui. Anak tidak bisa belajar dengan baik apabila dia lapar, merasa tidak aman/takut, lingkungan tidak sehat, tidak dihargai atau diacuhkan oleh pendidik atau temannya. Hukuman dan pujian tidak termasuk bagian dari kebutuhan anak, karenanya pendidik tidak menggunakan keduanya untuk mendisiplinkan atau menguatkan usaha

\footnotetext{
${ }^{1}$ novipujilestari61@gmail.com
} 
yang ditunjukkan anak. Dari beberapa penjelasan di atas ada beberapa yang belum diwujudkan di TPA Assakinah, sehingga kita tim pengabdian dari Universitas Muhammadiyah Malang berkeinginan untuk membantu mereka dalam hal penataan kualitas sumber daya manusia di TPA Assakinah serta membantu dalam pembuatan profil lembaga.

Data dan observasi yang tim lakukan di lapangan sebelum penyusunan proposal pengabdian ini, tim menemukan beberapa permasalahan yang dihadapi oleh mitra. Berikut beberapa permasalahan mitra yang berhasil tim rangkum dalam proposal ini: (1) Posisi Gedung yang bergabung dengan Balai Pengobatan Aisyiyah dan Kantor Nasiyatul Aisyiyah Dau yang mengakibatkan TPA ini jika dilihat dari luar kurang menarik dan lebih mirip dengan rumah sakit. (2) Gedung yang terlalu besar dan terkesan menyeramkan jika dilihat dari pinggir jalan atau tampilan luar. (3) Posisi dalam ruangan yang juga kurang ramah anak artinya karena posisi ruangan yang terlalu luas sehingga terkesan kosong dan tidak ada mainan yang bisa merangsang syaraf motorik anak. (4) Sumber Daya Manusia yang kurang sehingga belum fokus karena satu sumber daya bisa menangani beberapa anak dalam satu waktu. (5) Papan Nama untuk TPA ini juga belum ada karena sementara yang ada hanya banner tulisan nama TPA yang dipasang hanya pada satu sisi saja sehingga jika dari sisi yang berlawanan belum kelihatan. (6) Belum adanya Profil Perusahaan yang mendukung kegiatan lembaga ini, baik profil dalam bentuk modul maupun website yang bisa diakses dari luar oleh publik

\section{Materi dan Metode Pelaksanaan}

Kegiatan ini akan dilaksanakan dalam bentuk pelatihan dan penyuluhan mengenai standar Taman Penitipan Anak. Dengan demikian, pengurus maupun guru yang ada di TPA As Sakinah memiliki pandangan lain yang berbeda mengenai tata kelola TPA. Hal tersebut penting dilakukan untuk meningkatkan kualitas pengelolaan TPA As Sakinah. Tim pengusul juga akan mengusahakan terbentuknya kerjasama dengan beberapa pihak untuk menyediakan penambahan fasilitas mainan/tempat bermain anakanak yang bisa merangsang syaraf motorik mereka dengan beberapa mainan edukasi. Perbaikan ruangan dengan membuat ruangan tersebut menjadi lebih menarik dan ramah anak. Kegiatan ini akan dilaksanakan di TPA As-Sakinah yang beralamatkan di Jalan Margobasuki Rt 04 Rw 01 Dusun Dermo Desa Mulyoagung Kecamatan Dau Kabupaten Malang. Lama kegiatan selama 8 bulan.

\section{Hasil Dan Pembahasan}

Dalam pelaksanaan kegiatan ini, tim pengusul telah melakukan beberapa kali pertemuan sebagai upaya koordinasi dari bagaimana pengimplementasian program di lapangan. Pertemuan pertama dilakukan pada tanggal 7 Februari 2018, tim mengadakan pertemuan singkat terkait dengan kunjungan ke lokasi pengabdian. Dalam pertemuan tersebut, tim pengusul melakukan koordinasi terkait dengan pertemuan pertama antara tim pengusul dengan penanggung jawab pihak kedua. Dimana pihak kedua diwakili oleh Ibu Laili selaku kepala sekolah dari TPA As Sakinah, DAU. Dalam pertemuan tanggal 7 Februari tersebut, tim pengusul sepakat untuk datang melihat lokasi pengabdian pada tanggal 9 Februari 2018. Pada tanggal 9 Februari 2018, tim pengusul sebanyak tiga orang, melakukan kunjungan dan pertemuan pertama ke lokasi pengabdian. Dalam pertemuan dan kunjungan tersebut, tim bertemu dengan Ibu Laili sekaligus penanggung jawab dari pihak kedua.

Pada pertemuan tersebut, tim pengusul melakukan koordiinasi dengan penanggung jawab pihak kedua, terkait tentang apa dan bagaimana konsep teknis pengabdian yang akan dilakukan. Pertemuan tersebut menghasilkan beberapa kesepakatan seperti terkait dengan tema apa yang akan diimplementasikan untuk dekorasi ruangan. Tanggal penjadwalan dari dekorasi ruangan. Selain itu, tim pengusul juga menjadwalkan pertemuan kedua dengan pihak kedua, untuk mengambil beberapa gambar terkait dengan kegiatan siswa dan siswi yang ada di TPA As Sakinah dari pagi hingga sore hari.

Pertemuan pertama antara tim pengusul dengan pihak kedua, menghasilkan beberapa kesepakatan terkait dengan jadwal pertemuan kedua, serta bentuk dari dekorasi yang akan tim pengusul laksanakan dilapangan. Sebelum membuat company profile, tim sepakat dengan pihak kedua, untuk melakukan pendekorasian ulang terkait dengan ruangan yang ada di TPA As Sakinah. Tujuan pendekorasian ulang tersebut sebagai upaya tim pengusul mengubah tampilan ruang TPA As Sakinah, agar sesuai dengan apa yang diharapkan dan lebih Instragamabel saat dimuat dalam web.

Selanjutnya, pada tanggal 8 Maret 2018, tim pengusul mengadakan pertemuan lanjutan untuk membahas mengenai desain web dan jadwal pelaksanaan pendekorasian ulang ruang TPA As Sakinah. Salah satunya adalah penjadwalan pertemuan kembali dengan pihak kedua untuk melakukan pengukuran ruangan. Pengukuran ruangan sendiri dilakukan oleh tim pengusul pada tangal 12 Maret 2018. Dari hasil pengukuran ruangan ditemukan bahwa panjang raungan adalah 14,8 meter dengan lebar 7,6 meter. Tanggal 16 Maret-31 Maret tim pengusul melakukan pematangan dan penjadwalan untuk melakukan realisasi 
pendekorasian ulang ruang TPA As Sakinah.

Tanggal 6 April 2018, tim melakukan pertemuan lanjutan dengan pihak kedua, untuk mengkonfirmasi waktu pendekorasian. Karena hari aktif TPA As Sakinah adalah di hari Senin-Sabtu (setengah hari), maka pendekorasian pertama disepakati dilaksanakan pada tanggal 6 Mei 2018. Pada tanggal 1-5 Mei, tim melakukan persiapan untuk menyiapkan peralatan dan perlengkapan yang dibutuhkan untuk mendekorasi ruang TPA As Sakinah. Pada tanggal 6 Mei 2018, pukul 08.00 WIB dengan dibantu, lima mahasiswa, tim pengusul mulai melakukan pendekorasian ulang dengan cara mengecat beberapa petak dinding yang dirasa kurang layak untuk masuk ke dalam profile. Selain itu, tim pengusul juga sudah menyiapkan beberapa sticker dinding dengan berbagai macam gambar hewan serta tumbuhan. Tujuan dari penempelan beberapa sticker tersebut, agar ruang TPA As Sakinah terlihat lebih hidup dan bewarna dari pada sebelumnya.

Kegiatan dekorasi tahap kedua dilaksanakan pada tanggal 15 Mei 2018, pada tanggal tersebut, tim pengusul menyelesaikan beberapa pekerjaan teknis yang belum selesai dikerjakan pada tahap pertama. Proses terakhir dari dekorasi adalah mengecat beberapa bagian, dan juga mengisi beberapa dinding yang belum tertempel dengan sticker gambar. Pada tanggal 30 Juni 2018, adalah kegiatan pelatihan pembuatan web sederhana dari tim pengusul bersama dengan pengurus TPA As Sakinah.

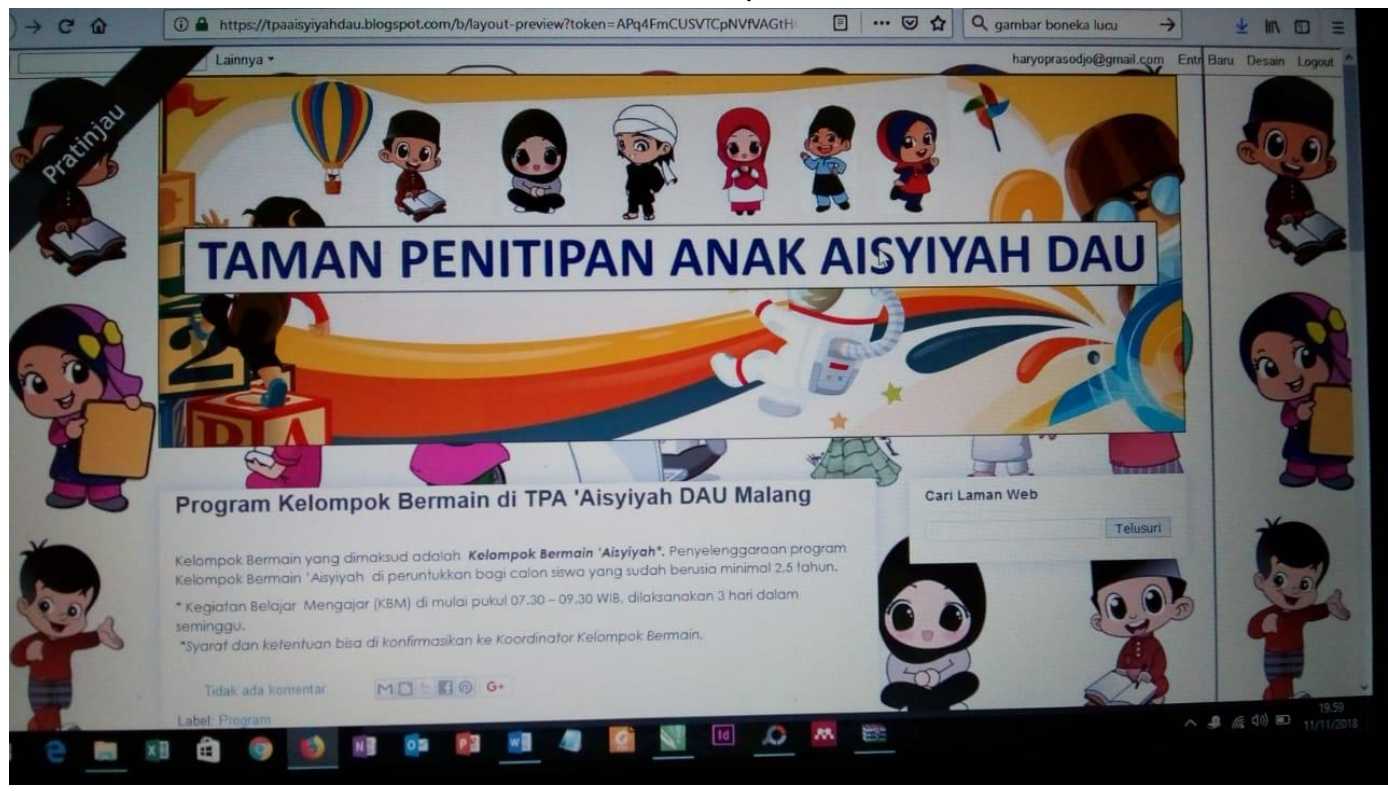

Gambar 1. Hasil pelatihan pembuatan website sederhana

Kegiatan pengabdian ini menurut tim kami masih ada beberapa yang perlu dilakukan evaluasi dan selanjutnya bisa diperbaiki yaitu terkait penghiasan cat halaman luar TPA yang masih belum bisa direalisasikan oleh Tim Pengabdian UMM. Hal yang menjadi kendala utama kami adalah terkait pendanaan yang memang tidak mencukupi untuk perbaikan sampai halaman luar, Jadi kegiatan kami terbatas pada hiasan atau dekorasi dalam ruangan, pembuatan website dan pelatihan untuk pengelola website.

\section{Kesimpulan dan Saran}

Kegiatan Program Pengabdian Kelompok yang dilaksanakan di TPA As Sakinah secara keseluruhan berjalan dengan baik. Pertama terkait dengan pemantapan ide untuk membuatkan website dan menghias sekolah untuk bisa dijadikan sekolah yang ramah anak didukung oleh pihak sekolah secara penuh. Untuk permintaan sekolah terkait menghias sisi luar sekolah belum bisa direalisasikan oleh tim kami karena memang terkendala dana. Tetapi secara keseluruhan mulai awal kegiatan sampai website selesai semua berjalan dengan lancar. Kami berharap dengan adanya website ini bisa mempermudah terkait informasi yang dibutuhkan oleh masyarakat luas untuk mengetahui sejauh mana latar belakang sekolah dan aktivitasaktivitas apa saja yang dilakukan di Taman Penitipan Anak ini 


\section{Referensi}

'Pengertian dan Definisi Internet', diakses melalui http://elib.unikom.ac.id/files/disk1/618/jbptunikomppgdl-fitrinim10-30855-10-unikom_f-i.pdf (01/ 12/ 2017)

'Definisi dan Pengertian Internet Menurut Para Ahli' (05/ 10/ 2017), diakses melalui https://kupdf.com/download/definisi-dan-pengertian-internet-menurut-paraahli_59d547c008bbc5325d686e7a_pdf (01/ 12/ 2017)

Hartono, Hamzah, 'Pengertian Website dan Fungsinya', diakses melalui http://ilmuti.org/wpcontent/uploads/2014/03/HamzahHartono_Pengertian_WEBSITE_Dan_Fungsinya.pdf (01/ 12/ 2017)

Anggiani, Septima Riyadi. Eko Retnandi. Asep Deddy, Dkk 'Perancangan Sistem Informasi Berbasis Website' Jurnal Algoritma Sekolah Tinggi Teknologi Garut, diakses melalui http://www.sttgarut.ac.id/jurnal/index.php/algoritma/article/viewFile/49/45 (01/ 12/ 2017)

Suyanto, Asep Herman. 'Web Service' (2007), diakses melalui http://www.jurnalkomputer.com/attachments/article/238/Web\%20Service.pdf (01/ 12/ 2017). 